Arch. Min. Sci. 62 (2017), 1, 3-12

Electronic version (in color) of this paper is available: http://mining.archives.pl

DOI 10.1515/amsc-2017-0001

\author{
JAROSLAV DVOŘÁČEK*, RADMILA SOUSEDÍKOVÁ*, TOMÁŠ VRÁTNÝ**, \\ ZDENKA JUREKOVÁ***
}

\title{
GLOBAL TUNGSTEN DEMAND AND SUPPLY FORECAST
}

\section{ŚWIATOWE PROGNOZY POPYTU I PODAŻY WOLFRAMU}

\begin{abstract}
An estimate of the world tungsten demand and supply until 2018 has been made. The figures were obtained by extrapolating from past trends of tungsten production from 1905, and its demand from 1964 . In addition, estimate suggestions of major production and investment companies were taken into account with regard to implementations of new projects for mining of tungsten or possible termination of its standing extraction. It can be assumed that tungsten supply will match demand by 2018 . This suggestion is conditioned by successful implementation of new tungsten extraction projects, and full application of tungsten recycling methods.
\end{abstract}

Keywords: tungsten supply, tungsten demand, estimate

Zaprezentowano szacunkową prognozę światowego popytu i podaży wolframu w roku 2018. Wartości liczbowe otrzymano poprzez ekstrapolację wielkości charakteryzujących trendy w produkcji wolframu od roku 1905 oraz trendy w zakresie popytu licząc od roku 1964. Ponadto, podano szacunkowe dane o wielkości produkcji, wzięto także pod uwagę firmy inwestujące w tym obszarze, uwzględniając realizacje nowych inwestycji w dziedzinie produkcji wolframu oraz możliwe zakończenie wydobycia. Przyjmuje się, że podaż wolframu roku 2018 zrównoważy popyt. Założenie to uwarunkowane jest zakończeniem realizacji nowych inwestycji w dziedzinie wydobycia oraz zastosowaniem na pełną skalę działań mających na celu recykling i odzysk wolframu.

Słowa kluczowe: popyt na wolfram, podaż wolframu, oszacowanie

* FACULTY OF MINING AND GEOLOGY, VŠB-TECHNICAL UNIVERSITY OF OSTRAVA, OSTRAVA, 70833, CZECH REPUBLIC. E-MAIL: jaroslav.dvoracek@vsb.cz,radmila.sousedikova@vsb.cz

** ČSAD OSTRAVA, A.S., OSTRAVA, 70200, CZECH REPUBLIC. E-MAIL: vratny@cova.cz

*** LARUMO SERVIS, S.R.O., KARLOVY VARY, 36001, CZECH REPUBLIC. E-MAIL: Zjurekova@seznam.cz 


\section{Introduction}

Tungsten is certainly a strategic metal as it has significant use in military and many other industrial applications. The high temperature stability of tungsten per se and the strength of tungsten alloys make it useful in industrial applications. Its most common uses are in hardening steel, and for making drill tips and cutting equipment. It is therefore used throughout the mining, metalworking, petroleum, construction, jewellery and aerospace industries.

Tungsten demand is influenced by the vicissitudes of world economy and occurrence of war events. The tungsten supply relates to its prices or, as the case might be, the stockpiling strategies of some governments. The balance of tungsten demand and supply and its price is causally connected: tungsten low prices imply limitation of its mining capacities, and tungsten high price initiates implementation of new mining projects. Nonetheless, free market mechanisms are tempered with government interventions.

The tungsten dominant market position has been taken by the People's Republic of China. China's product market share in 2012 is estimated to be 83\% (British Geological Survey, 2012). Increases in China's tungsten supply imply increases in demand. Much of the literature refers to the balance of tungsten supply and demand. Different future development scenarios exist: Mismatch of demand and supply-demand increases lag behind supply increases (Merriman, 2013), imbalance of supply and demand-demand increases faster than supply (Almonty Industries, 2012), zero gap scenario-balance between tungsten growing demands is matched by increasing supplies (Merriman, 2014).

The statistics until 2013 provided for tungsten demand and supply forecasts up to 2018 .

\section{Method}

The estimate of world tungsten supply and demand was based on long-term statistics of the data concerned that were interpolated by trend curves. The curves were extrapolated for a future period of five years in the form of an interval prognosis delimitating the period's bottom and top boundaries.

\subsection{Tungsten supply}

The tungsten supply can be from primary or secondary resources. The primary source for tungsten production is from wolframite and scheelite. In addition, stockpiles created by tungsten producers during the period of supply/demand imbalance or strategic material stockpiles of USA, Russia, and China can be included among primary tungsten supplies. The latter was created in the past and the countries were interested in putting the stockpiled tungsten on the market. Various forms of tungsten-containing scrap represent secondary sources of the material supply.

Statistics on the global production of tungsten, for the period 1905-2013, was provided by the U.S. Geological Survey $(2015,2014)$. The data files provided are basically of uniform character and are released without restrictions to other publication or use. The statistics distinguishes two groups of tungsten primary supplies, which is conditioned by two different reporting terminologies. Sometimes, American producers report on 'mine production', sometimes they talk about 'shipments'. These two 'categories' usually differ if both figures are given for a specific year. 
For that reason, the 'tungsten supply' is considered to be production from primary mining and processing capacities.

It is obvious that a complete accounting for tungsten supply and demand statistics worldwide is rather difficult. Very often the authors refer to inaccessibility of data from some countries, which deficiency is sometimes remedied by simple estimates. It is necessary to come to terms with this uncertainty as better references do not exist. It is a kind of paradox that for a period of 14 years, no statistics on American production of tungsten has been provided.

Because of the period timespan, unification of the disposable data was necessary. The unification was made by the following methods:

I. All data were converted to metric tons, that is, $1000 \mathrm{~kg}$ of pure tungsten in tungsten concentrate. In the past, the so-called short tons were used ( 1 metric ton $=1.1023$ short tons) or pounds (1 pound $=0.4536 \mathrm{~kg})$.

II. In all periods, the parameter, 'production' was employed. The parameter 'shipment' was converted as follows:

- If American statistics report on 'production' but world statistics on the American production of tungsten talk about 'shipments', the latter is substituted by 'production', and the world tungsten supply statistics is adapted accordingly.

- Sometimes both 'production' and 'shipment' data are given for US. If this is the case, the coefficient, $k=$ production/shipment, is calculated and its average, $k=1.0224$ is employed for the calculation of the 'production' from the 'shipment', namely:

$$
\text { production }=\text { shipment } \times 1,0224
$$

Data on the American mining company production were used for calculation of worldwide figures.

III. In the period of 14 years (1988-1994, 2007-2013), there has been no report whatsoever on American shipments or production of tungsten. Only the number of tungsten ore mines is given. As in other periods, not only the production of tungsten is reported, but also the number of active tungsten mines is specified, making it possible to determine an average production of tungsten of a single mine per annum, which is 690 tons. If the number of active US mines is known, the missing data can be completed and the related world statistics adapted.

The results are illustrated by the pointed curve in Fig. 1. It shows production increases between WWI and WWII, during Korea and Vietnam conflicts, decreases at the beginning of the 1930s as implications of the world economic crisis, and also decreases after 2008 related to the financial crisis.

The development of empirical figures in time can be described by a trend curve. The latter's specification is based on its approximation accuracy, which is specified by the coefficient of determination, $R^{2}$. Another criterion of specification can be that of the course of the trend curve in the period of forecast.

The extrapolated values should take into account an actual production outcome, namely, that it will be finally conditioned by:

- Termination of mining at unworkable reserve localities,

- Accretion of new mining capacities in the period investigated. 


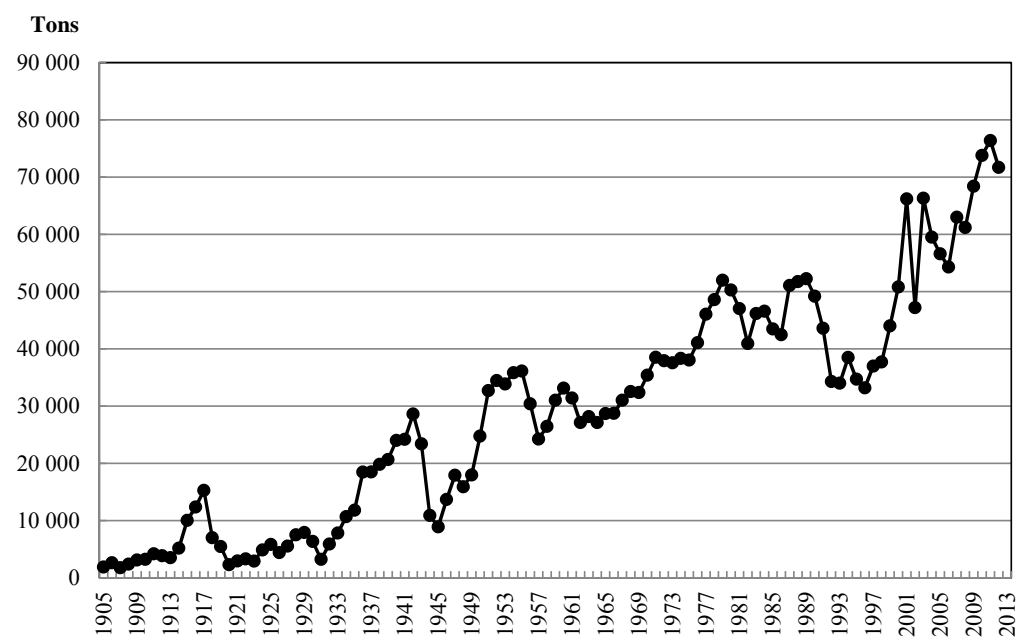

Fig. 1. Global supply of tungsten

Source: Own elaboration based on U.S. Geological Survey data

\subsection{Tungsten consumption}

Again, the principal source of information was provided by the Minerals Yearbooks, 19641994, U.S. Geological Survey (2015) completed by UNO information on the matter. Until 1988, these were the only accessible sources of systematically unified information. For the period, 1989-2013, the world data on tungsten demand yielded services of several Internet providers. Especially analysis of the published charts could provide for inferring the figures needed (International Tungsten Industry Association, 2011), (North American Tungsten Corporation Ltd. 2012),

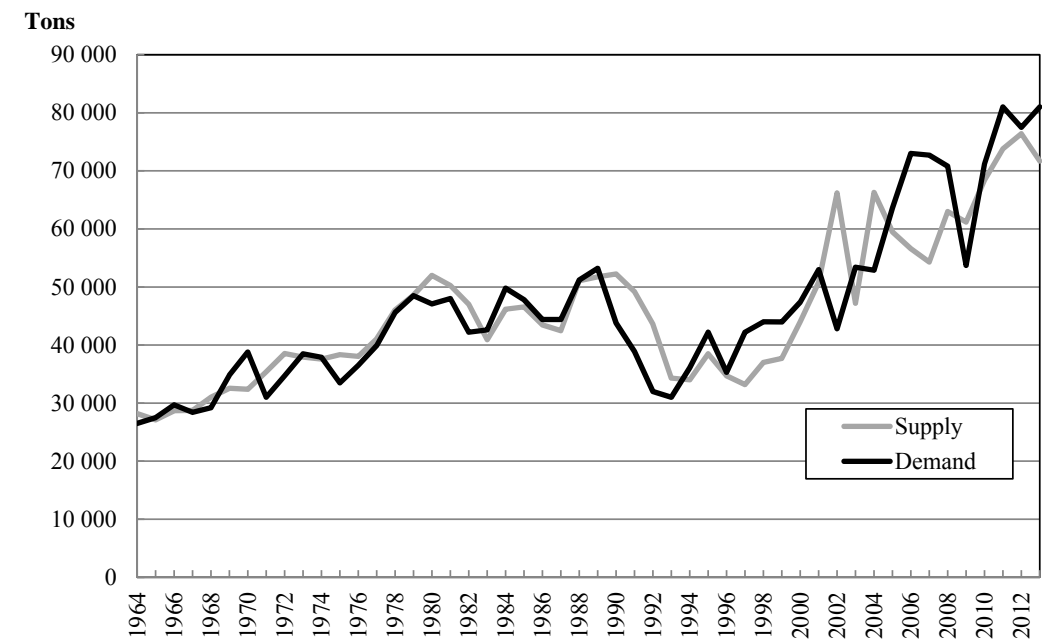

Fig. 2. Global tungsten demand and supply Source: Own elaboration based on U.S. Geological Survey data 
(Metal-pages, 2013), (Wolf Minerals Limited, 2010). In view of some inconsistence of data coming from different sources, an arithmetic average was ascertained for the tungsten demand of a specific year. The empirical values were interpolated by a trend curve and extrapolation up to 2018 was performed. The graphics of the Fig. 2 shows the empirical tungsten supply and demand figures.

Fig. 2 makes it obvious why two indicators, namely 'production' and 'shipment', are distinguished by the U.S. Geological Survey Minerals Yearbooks (U.S. Geological Survey, 2015): sometimes demand is in excess of supply and the mismatch necessitated completion by drawing from stock reserves. It should be taken into account that part of the tungsten demand was balanced by secondary resources.

\section{Results}

\subsection{Tungsten Supply Forecast}

Based on the aforementioned criteria, the empirical data, for the period 1905-2013, were interpolated by fourth- and fifth-order polynomial functions in the form of equations:

$$
\begin{gathered}
Y=0.0042 x^{4}-0.9131 x^{3}+65.239 x^{2}-1114.2 x+7995,8 \quad R^{2}=0.9033 \\
Y=0.0001 x^{5}-0.0252 x^{4}+1.9684 x^{3}-54.452 x^{2}+801.57 x+521.92 \quad R^{2}=0.9132
\end{gathered}
$$

where $\mathrm{Y}$ represents world production in tons of tungsten contained in tungsten concentrate; $\mathrm{x}$ is the time from $1,2, \ldots$ up to $114 ; R^{2}$ is the coefficient of determination.

The fourth-order polynomial function determined the forecast lower boundary. The fifth-order polynomial function provided for delimiting the forecast upper boundary. For 2018, the tungsten demand forecast interval of one hundred ascertained averages is 84,700-103,700 tons, see Fig. 3 .

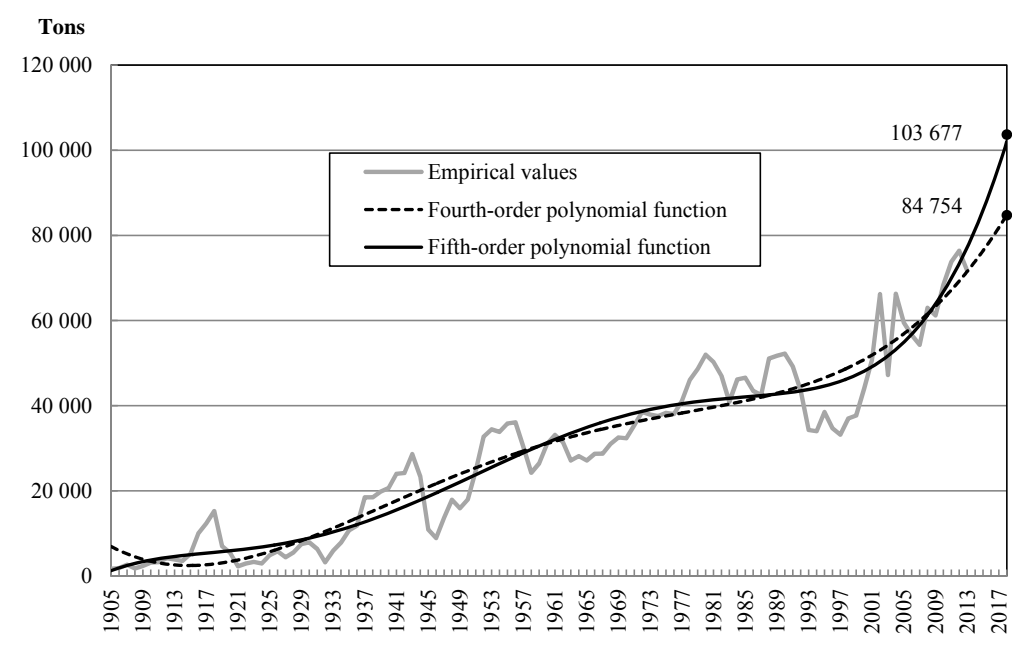

Fig. 3. Interval forecast for global tungsten supply Source: Own elaboration based on U.S. Geological Survey data 
This interval is the outcome of mathematical calculation. Presently, some mines are known to be terminating their operations by 2018 , and there are others that will start tungsten extraction in the near future. The Cantung Mine, Canada, belongs to the first group, which should cease their operations in 2016-2017 implying tungsten production loss of 2,800 tons of tungsten per annum (Merriman, 2013), (Resource Investor, 2004). Locations where tungsten will be extracted in future are Nui Phao, Vietnam, La Parilla and Barruecopardo, Spain, Hemerdon, UK, Watershed and Mt. Carbine, Australia, and Sisson, Canada. These are projects that will be actually implemented or are in a stage of advanced development, which are envisaged to be materializing by 2018 . If the plan of action is adhered to, tungsten production will increase by 16,700 tons in 2018 (Resource Investor, 2014), (Metal-pages, 2012), (Streetwise reports, 2014).

As such, the difference between closed and new tungsten facilities is 13,900 tons of tungsten as regards the forecast target year. Based on the supply, as of 2013, the hundred ascertained average of tungsten demand tungsten supply worldwide can be forecasted to be 85,600 tons. The estimate is within the forecast interval next to its lower boundary.

\subsection{Tungsten Demand Forecast}

The empirical figures for tungsten demand, for the period 1964-2013, were interpolated by second- and third-order polynomial functions expressed by the equations:

$$
\begin{gathered}
Y=19.3254 x^{2}-206.9340 x+34989.2281 \quad R^{2}=0.6931 \\
Y=2.2337 x^{3}-151.5530 x^{2}+3313.6089 x+19291.1939 \quad R^{2}=0.8309
\end{gathered}
$$

where $Y$ represents world tungsten consumption in tons; $\mathrm{x}$ is the time from $1,2, \ldots 55$; and $R^{2}$ is the coefficient of determination.

The second-order polynomial function determined the lower boundary of the forecast. The third-order polynomial function provided for delimiting the upper boundary of the forecast. For 2018 , the tungsten demand forecast interval in one hundred ascertained averages is $84,100-114,700$ tons.

The supply/demand coefficients of determination, which determine concurrence of empirical and theoretical values (Hindls et al., 2007), differ. The tungsten demand coefficients are smaller than those of its supply counterparts. For check-up purposes, other Internet forecasts were taken into account and the average tungsten demand in 2018 was determined (North American Tungsten Corporation, 2012), (Wolf Minerals Limited, 2010), (Wolf Minerals Limited, 2015), (Ormonde Mining Plc, 2014), (Proactive investors Australia, 2012). The rounded one hundred ascertained average of this demand was 102,500 tons of tungsten. The average consumption lies within the interval forecast next to its upper limit boundary. Nevertheless, aiming at reducing our interval span, only two Internet forecasts were employed to determine the bottom and top tungsten consumption values (Proactive investors Australia, 2012), (Wolf Minerals Limited, 2015). These parameters were chosen in preference as they related to sufficiently long prognostic terms and were presented by renowned sources of forecast information. The results of demand trends and interval forecast for 2018 were evaluated to be between 99,300 and 109,400 tons (one hundred rounded off figures), as illustrated by Fig. 4. 


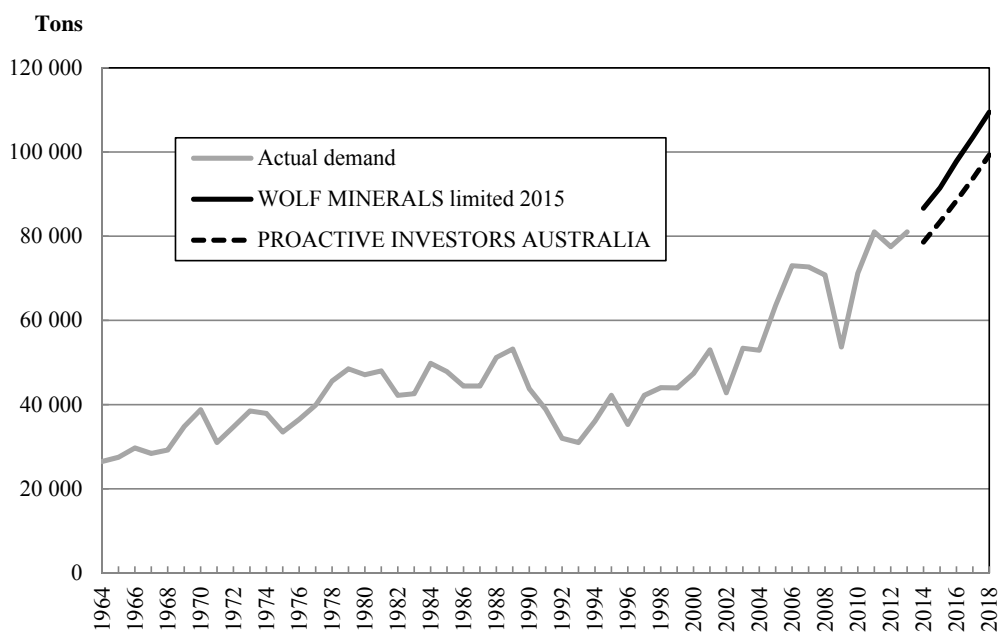

Fig. 4. Interval forecast for tungsten demand

Source: Own elaboration based on U.S. Geological Survey data

\section{Discussion and Conclusion}

The aforementioned information can be combined to provide for forecasting the balance between demand (consumption) and supply (production) of tungsten. The period, 2014-2018, is illustrated by Fig. 5 .

The supply and demand forecast bottom and upper limit boundaries implied in 3.1 and 3.2 are highlighted as 'pessimistic supply/demand extrapolation' or 'optimistic supply/demand ex-

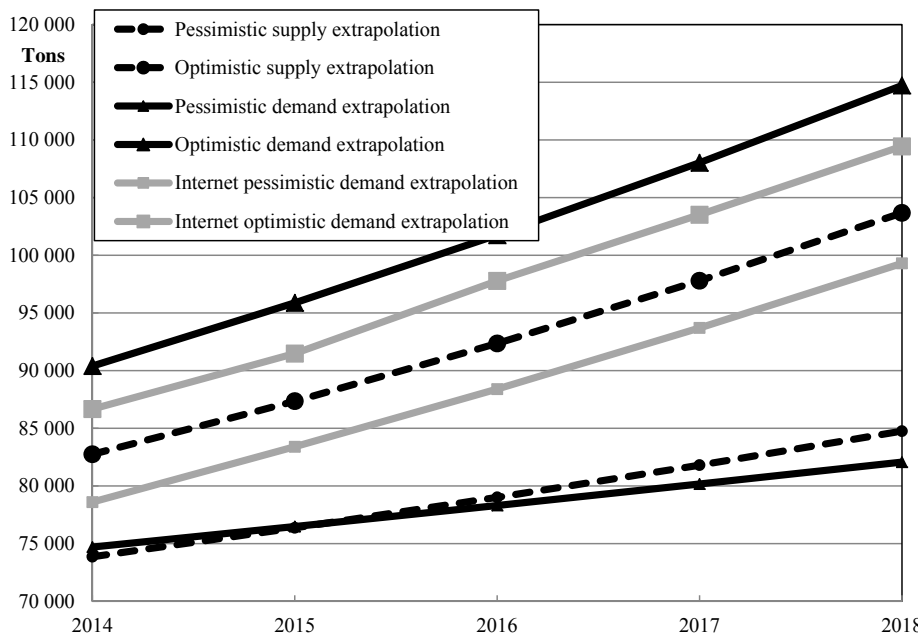

Fig. 5. Tungsten demand and supply balances forecast Source: Own elaboration 
trapolation' respectively. The demand bottom and upper limit boundaries adopted from Internet (Wolf Minerals Limited, 2015), (Proactive investors Australia, 2012), are designated as 'Internet pessimistic demand extrapolation' and 'Internet optimistic demand extrapolation' respectively. If Internet data and extrapolations of historical data are compared, it can be concluded that future tungsten supplies will be as follows:

- Tungsten future supplies meet demands of the forecast bottom boundary,

- Tungsten upper limit boundary demand outstrips tungsten future supplies.

The term tungsten supply (production) means the output of mining and processing activities (primary resources). Nonetheless, also secondary supply sources of tungsten recycling should be taken into account. The tungsten recycling ratio is forecasted to be between $26 \%$ and $35 \%$ of supply (Nickels, 2014), (Streetwise reports, 2013). The forecast of minimum and maximum average amounts of recycled tungsten reach the values of 25,800 and 31,600 tons, respectively. This scenario means that there is no mismatch between tungsten demand and supply or that the demand is fully met also by scrap recycled tungsten.

Nevertheless, two problems should be highlighted. The first concerns the fact that although in the past decade, the ever growing supply ratio of recycled tungsten could meet the demand, a 35\% limit of recycled tungsten is considered to be a possible maximum (Streetwise reports, 2013). The growing demand can be only met by implementation of new mining projects, which implies another problem, namely, that new projects cannot be always be implemented as planned. For example, the project, Barruecopardo, which initially should have been in production by 2012 (Ormonde Mining Plc, 2011) but which was gradually postponed to 2016 (Tungsten Investing News, 2015). The principal reason for such postponements is in the demanding procedures of documentation and financial provisions.

To put it in a nutshell, the tungsten demand and supply forecast has been founded on extrapolation of historical data. The method of extrapolation assumes that past factors of influence are also valid for future. The extrapolated data were completed by forecasts of mining and investment companies and taking into consideration realization of new projects for tungsten mining, and assumption of future demands. Regarding the already mentioned tungsten future market options, we can expect rather a balanced scenario in 2018 if

- There is no major delay of implementing new tungsten extraction project,

- Recycling of tungsten is fully utilized.

Any deviation of this trend will be reflected by prices of this mineral commodity.

\section{Acknowledgment}

The authors gratefully acknowledge the help of the Technology Agency of the Czech Republic that financed the article's investigation in the framework of project No. TE02000029, Competence Centre for Effective and Ecological Mining of Mineral Resources.

\section{References}

Almonty Industries, 2012. Tungsten. Demand and pricing. [online]. [Accessed: 2014-10-22]. Available from: http://www.almonty.com/tungsten/demand_pricing/ 
BRITISH GEOLOGICAL SURVEY, 2012. World mineral production 2008-12. Keyworth, Nottingham: British Geological Survey, p. 106.

Hindls R., S. Hronová S., Seger J., 2007. Statistika pro ekonomy. 8. vydání, Professional Publishing, Praha, p. 204.

International Tungsten Industry Association. 2011. Information on tungsten: sources, properties and uses. [online]. [Accessed 2014-10-22]. Available from: http://www.itia.info/tungsten-primary-uses.html

Metal-pages, 2012. World Tungsten Report, September 2012. [online]. [Accessed 2014-11-28]. Available from: http:// blog.metal-pages.com/wp-content/uploads/2012/09/WorldTungsten_201209.pdf

Metal-pages, 2013. World Tungsten Report, November 2013. [online]. [Accessed 2014-11-27]. Available from:

http://www.argusmedia.com/ /media/Files/PDFs/samples/worldTungsten_201311.pdf?Ia=en.

Merriman D., 2013. Tungsten supply-where does the future lie? [online]. [Accessed 2015-10-25]. Available from: http:// www.mining-journal.com/reports/tungsten-keeping-up-with-demand

Merriman D., 2014. Tungsten market set to undergo further changes to 2018. [online]. [Accessed 2014-03-06]. Available from:

http://www.google.cz/url?sa=t\&rct=j\&q=\&esrc=s\&source=web\&cd=1\&ved=0CCAQFjAA\&url=http $\% 3 \mathrm{~A} \% 2 \mathrm{~F} \% 2 \mathrm{Fw}$ ww.roskill.com\%2Fnews\%2Ftungsten-market-set-to-undergo-further-changes-to-2018\%2Fat download\%2Fattachment1\&ei=8M19VJrdHOfXyQPR_oKACA\&usg=AFQjCNEVw2G88tBndesxhzpmvdTu1WiQIw.

Nickels L., 2014. Tungsten demand to slow, but good news for alloys and hardmetals. Materialstoday 11 June 2014. [online]. [Accessed 2015-01-10]. Available from:

http:// www.materialstoday.com/metal-industry/news/tungsten-demand-to-slow-but-good-news-for-alloys/

North American Tungsten Corporation Ltd., 2012. North American Tungsten, the tungsten mining company. Tungsten market overview. [online]. [Accessed 2015-01-07]. Available from:

http://www.natungsten.com/i/pdf/CorporatePresentation.pdf

Ormonde Mining Plc, 2011. Mine Development and Exploration in Spain. Barruecopardo Tungsten Project. January 2011. [online]. [Accessed 2015-01-16]. Available from:

http://www.ormondemining.com/uf/Ormonde\%20Presentation\%203-1-11.pdf

Ormonde Mining Plc, 2014. Barruecopardo. An essential, secure supply of tungsten. March 2014. [online]. [Accessed 2015-01-9]. Available from:

http://ormondemining.com/uf/Company\%20Presentations/Ormonde\%20Mining\%20Corporate\%20Presentation\%20 Mar\%202014\%20(Final).pdf

Proactive investors Australia, 2012. Tungsten Mining looks to ride demand wave, admitted to ASX. December 14, 2012. [online]. [Accessed 2015-01-10]. Available from:

http://www.proactiveinvestors.com.au/companies/news/37347/tungsten-mining-looks-to-ride-demand-wave-admittedto-asx-37347.html

Resource Investor, 2014. A catch-22. Q\&A with Tungsten Market Research's Mark Seddon, June 10, 2014. [online]. [Accessed 2015-01-15]. Available from:

http://www.resourceinvestor.com/2014/06/10qa-a-tungsten-catch-22?page=1

Streetwise reports, 2013. Tungsten Enters the Limelight with Bullish Fundamentals: Ken Chernin. Source: Brian Sylvester of The Metals Report (4/16/13). [online]. [Accessed 2015-01-16]. Available from:

http://www.theaureport.com/pub/na/tungsten-enters-the-limelight-with-bullish-fundamentals-ken-chernin

Streetwise reports, 2014. We Need More Tungsten, But Projects Can't Find Funding. Source: Kevin Michael Grace of The Mining Report (6/10/14). [online]. [Accessed 2014-12-03]. Available from:

http://www.theaureport.com/pub/na/mark-seddons-catch-22-we-need-more-tungsten-but-projects-cant-find-funding

Tungsten Investing News, 2015. Ormonde Receives Funding for Barruecopardo Project. [online]. [Accessed 2015-0428]. Available from:

http://www.tungsteninvestingnews.com/5565-ormonde-receives-funding-for-barruecopardo-project.html

U.S. Geological Survey, 2014. Historical Statistics for Mineral Commodities in the United States. [online]. [Accessed 2014-11-03]. Available from:

http://minerals.usgs.gov/minerals/pubs/historical-statistics/ 
U.S. Geological Survey, 2015. Tungsten Statistics and Information. [online]. [Accessed 2014-11-03]. Available from: http://minerals.usgs.gov/minerals/pubs/commodity/tungsten/index.html

Wolf Minerals Limited, 2010. Tungsten Market Update - Price and Demand to remain strong. $30^{\text {th }}$ November 2010. [online]. [Accessed 2015-01-07]. Available from:

http://www.wolfminerals.com.au/IRM/Company/ShowPage.aspx/PDFs/1117-78862210/TungstenMarketUpdate

Wolf Minerals Limited, 2015. The Hemerdon Project (Drakeland Mine). Information Pack. January 2015. [online]. [Accessed 2015-01-08]. Available from:

http://www.wolfminerals.com.au/IRM/Company/ShowPage.aspx?CategoryId=375\&CPID=1480\&EID=94234852\&masterpage $=3$ 